\title{
The Effect of Phosphorus and Potassium on the Growth and Quality of Viola (Viola cornuta L.) Seed Production
}

\author{
Alfa Sada Saputra*, Suprihati and Endang Pudjihartati \\ Department of Agroecotechnology, Faculty of Agriculture and Business, \\ Universitas Kristen Satya Wacana, Salatiga, Indonesia \\ "Corresponding author: alfasada27@gmail.com
}

\begin{abstract}
Viola cornuta $\mathrm{L}$. is an ornamental plant that is primarily propagated by high-quality seeds that have high demand in subtropical countries. The use of fertilizers according to recommendations results in the growth of parent plants below the standard. Furthermore, seed production is generated below $2 \mathrm{~g}$ per plant and the seed germination capacity is below $80 \%$. In addition, phosphorus $(\mathrm{P})$ and potassium $(\mathrm{K})$ nutrients can increase the growth and seed production of the plants, including ornamental plants. The study aimed to determine the influence of $\mathrm{P}$ and $\mathrm{K}$ nutrients on growth and seed production of V. cornuta L. Research was carried out in November 2018 - January 2019 at PT. Selektani Horticulture, Ngablak, Magelang. There were seven treatments with four replications. Experiments were arranged according to the Randomized Complete Block Design (RCBD). Plants were grown in 51 volumepolybags. Fertilization was done by watering the planting media. Analysis of variance was performed at $95 \%$ accuracy. The study shows that $\mathrm{P}$ and $\mathrm{K}$ nutrients have a highly significant effect on height, number of flowers, number of seed per capsule, seed production and germination energy and significantly affected the number of leaves. The addition of both $\mathrm{P}$ and $\mathrm{K}$ fertilizers in the vegetative and $\mathrm{P}$ in the generative stage (P6) can result in the productivity of $3.28 \mathrm{~g} \mathrm{plant}^{-1}$ and produce germination energy $\geq 90 \%$. It is recommended for increasing growth and seed production.
\end{abstract}

Keywords: phosphorus; potassium; plant nutrition; Viola seeds; seedling growth

Cite this as: Saputra, A. S., Suprihati, \& Pudjihartati, E. (2020). The Effect of Phosphorus and Potassium on the Growth and Quality of Viola (Viola cornuta L.) Seed Production. Caraka Tani: Journal of Sustainable Agriculture, 35(1), 12-22. doi: http://dx.doi.org/10.20961/carakatani.v35i1.33618

\section{INTRODUCTION}

Extension seed of Viola (Viola cornuta L.) or usually called horned pansy is currently high in demand especially for bedding plants and landscape gardens in the countries with four seasons. This research was conducted to increase the production of viola seeds to fulfill market demand as one of the efforts in the sustainable agriculture practices (Rawat et al., 2016). For example, in 2016, the Netherlands, Germany and Poland imported $427 \mathrm{~kg}, 40 \mathrm{~kg}$ and $17 \mathrm{~kg}$ viola seeds each month in average (Zabua tech and data service, 2018). To fulfill the demand of extension seed of viola, the parent plants are grown in the tropical countries such as Indonesia.

There are problems in viola seed production in tropical countries. The productivity of viola female parent plants is quite low; the average seed yield of each plant is only $2 \mathrm{~g}$ in two months period of pollination. The quality of the seeds is also low. One of the representative variable, which is the germination energy is lower than $80 \%$ (personal communication). This germination value is below the standard of hybrid seed market (Komalasari and Fauziah, 2011). Even though the production is low, the cost of producing F1 seeds

\footnotetext{
* Received for publication August 8, 2019

Accepted after corrections October 8, 2019
} 
in Indonesia is lower so the production of these seeds continues to be pursued.

The low productivity of viola is influenced by non-optimal growing environment during the vegetative and generative stages (Lazcano and Dominguez, 2010). Due to these conditions, the plant provides a physiological response. This disrupts the growth and development of the generative stage of viola female parent plants. The consequence is below market standards-seed production and quality. Besides that, viola plants naturally can self-pollinate. Pollen that falls on the stigma will germinate in the stigma cavity with a percentage of $37 \%$ to $47 \%$. The results of the research on Viola tricolor plants show that pollen can be viable to eight days before being degraded. The number of pollen granules is 4,000 to 7,000 grains per flower (Miyajuma, 2006). The possibility of low productivity and quality due to incompatibility or physiological response can be avoided.

Furthermore, the environmental factors that contribute to the growth and development of viola female parent plants include water, light intensity and nutrient availability (Miyajuma, 2006). However, the availability of water can be fulfilled by periodic watering and the intensity of light can be controlled by providing room shading. Nutrient availability needs to be studied further. This is because precise nutrient availability on the vegetative and generative stages can increase the production and the quality of viola seed at the end of growth. Actively growing plants will absorb $\mathrm{P}$ and $\mathrm{K}$ nutrient, starting in the vegetative stage and then translocate from leaves to flowers or seeds in the generative stage (Ma'rufah, 2008; Maulana et al., 2015)

Lack of nutrients initiates slow growth and influences the Antithesis to Silking Intervals (ASI), causing ASI to increase. The increase in the difference in ASI can affect the formation of imperfect seeds. Then it is necessary to increase nutrient availability through the fertilization process. Fertilization to improve plant performance and physiological quality of viola seeds should be done at the right type and time. Vegetative organs of Viola odorata contain high amounts of $\mathrm{N}$ and $\mathrm{K}$. High phosphate content is absorbed on the generative organs such as flowers and seeds (Fan and Morard, 1993).

The addition of $\mathrm{P}$ and $\mathrm{K}$ nutrients at the production of viola seeds is carried out with the support of inorganic fertilizers. Several types of fertilizers that can be used are Hortigro B (HB) (N $11 \%, \mathrm{P} 41 \%, \mathrm{~K} 11 \%)$ and Hortigro $\mathrm{C}(\mathrm{HC})(\mathrm{N}$ $12 \%, \mathrm{P} 12 \%, \mathrm{~K} 37 \%$ ). Besides the low price, the availability of these types of fertilizers in the market is the reason for using them. They are available for plants when applied to soil media.

Similar research shows that the addition of $\mathrm{P}$ and $\mathrm{K}$ to organic fertilizers in Viola cornuta plants increases the growth and development of the plants. This is indicated by an increase of vegetative organs such as plant height up to 13.19 $\mathrm{cm}$ and the number of leaves up to 27 sheets (Janicka and Dobrowolska, 2013). Furthermore, the development of the generative organ is specified by an increase in the number of flowers up to 20 flowers per plant and an increase in productivity measured through a seed weight per plant, which is $18.78 \mathrm{~g}$ on ornamental plant such as Tagetes erecta L. On the quality of the extension seeds, $\mathrm{P}$ and $\mathrm{K}$ fertilizer increased the germination to $90 \%$ on marigold (Aslam et al., 2016) and $98 \%$ on the other plants (Lesilolo, 2012). Based on this background, this study was conducted to determine the effect of $\mathrm{P}$ and $\mathrm{K}$ fertilizers on the growth, seed production and germination energy of viola (Viola cornuta L.) female parent plants.

\section{MATERIALS AND METHOD}

The research was conducted at PT. Selektani Horticulture greenhouse, Magelang, during the period of November 2018 - January 2019. The fertilizer combination includes Hortigro F (HF) (N 19\%: P 19\%: K 19\%), CNO fertilizer (N 15\%: P 0\%: K 0\%: Ca 26.5\%), Magnisal fertilizer (N 11\%: P 0\%: K 0\%: Mg 16\%), HB (N 11\%: P 41\%: $\mathrm{K} 11 \%)$ and $\mathrm{HC}(\mathrm{N} 12 \%$ : $\mathrm{P} 12 \%$ : K 37\%). Combinations of each type of fertilizer resulted in seven types of treatments with various levels of $\mathrm{N}$, $\mathrm{P}$ and $\mathrm{K}$ content. Each treatment was repeated four times then resulted in 28 experimental units. Experiments were arranged according to the Randomized Complete Block Design (RCBD). Details of the seven treatments tested on female viola plants are shown in Table 1.

Viola stock seeds were sown in a tray containing mixed seedling media (sand and cocopeat equaling in volume) and then kept in a growth chamber with a temperature of $18^{\circ}-22^{\circ} \mathrm{C}$ and light intensity of 1000 lux for five days (Oh et al., 2010). Seedlings were maintained for the next 35 days after the sowing (Demir et al., 2011). The 
seedlings were transplanted in a 51-polybag with a medium containing 2,51-rice husk and 2,51-soil (equal in volume). The vegetative stage of viola plants was measured until the plants were aged two months after sowing. After that, viola plants were in a generative stage that was characterized by the appearance of flowers. The pollination process was done by hand pollination. The pollination stage ended after 10 weeks and was followed by harvest period of 20 days after the first pollination.

Table 1. Type of treatments in vegetative and generative stage

\begin{tabular}{lll}
\hline \multicolumn{1}{c}{ Treatments } & \multicolumn{1}{c}{ Vegetative stage $\left(1 \mathrm{~L} \mathrm{~L}^{-1}\right)$} & \multicolumn{1}{c}{ Generative stage $\left(1 \mathrm{~g} \mathrm{~L}^{-1}\right)$} \\
\hline P0 (Standard) & $\mathrm{HF}+\mathrm{CNO}+$ Magnisal & $\mathrm{HF}+\mathrm{CNO}+\mathrm{HB}+\mathrm{HC}$ \\
P1 (+P Veg) & $\mathrm{HF}+\mathrm{CNO}+$ Magnisal + HB & $\mathrm{HF}+\mathrm{CNO}+\mathrm{HB}+\mathrm{HC}$ \\
P2 (+K Veg) & $\mathrm{HF}+\mathrm{CNO}+$ Magnisal + HC & $\mathrm{HF}+\mathrm{CNO}+\mathrm{HB}+\mathrm{HC}$ \\
P3 (+PK Veg) & $\mathrm{HF}+\mathrm{CNO}+$ Magnisal $+\mathrm{HB}+\mathrm{HC}$ & $\mathrm{HF}+\mathrm{CNO}+\mathrm{HB}+\mathrm{HC}$ \\
P4 (+P Veg +P Gen) & $\mathrm{HF}+\mathrm{CNO}+$ Magnisal + HB & $\mathrm{HF}+\mathrm{CNO}+\mathrm{HB}+\mathrm{HC}+\mathrm{HB}$ \\
P5 (+K Veg +P Gen) & $\mathrm{HF}+\mathrm{CNO}+$ Magnisal + HC & $\mathrm{HF}+\mathrm{CNO}+\mathrm{HB}+\mathrm{HC}+\mathrm{HB}$ \\
P6 (+PK Veg +P Gen) & $\mathrm{HF}+\mathrm{CNO}+$ Magnisal + HB + HC & $\mathrm{HF}+\mathrm{CNO}+\mathrm{HB}+\mathrm{HC}+\mathrm{HB}$ \\
\hline
\end{tabular}

Note: Number followed by the same letter in same row is not significant at $p 0.05$ according to DMRT $\mathrm{P} 0=$ Vegetative $(\mathrm{HF}+\mathrm{CNO}+$ Magnisal $)$, generative $(\mathrm{HF}+\mathrm{CNO}+\mathrm{HB}+\mathrm{HC}) ; \mathrm{P} 1=$ Vegetative (standard $+\mathrm{HB}) ; \mathrm{P} 2=$ Vegetative $($ standard $+\mathrm{HC}) ; \mathrm{P} 3=$ Vegetative $($ standard $+\mathrm{HB}+\mathrm{HC}) ; \mathrm{P} 4=$ Vegetative $($ standard $+\mathrm{HB})$, generative (standard $+\mathrm{HB}) ; \mathrm{P} 5=$ Vegetative $($ standard $+\mathrm{HC})$, generative $($ standard $+\mathrm{HB}) ; \mathrm{P} 6=$ Vegetative (standard $+\mathrm{HB}+\mathrm{HC}$ ), generative (standard $+\mathrm{HB}$ )

Furthermore, during the vegetative and generative stages, the parent plants were fertilized according to each treatment. Viola female parent plants were fertilized with $100 \mathrm{ml}$ of fertilizer mixture solution for each polybag. At the end of the study, seeds were harvested and a germination test was conducted with the Rolled-Paper Test method.

Plant's performance was evaluated by measuring plant height, number of leaves, number of flowers, number of seeds per capsule, seed production and germination energy as seedling growth evaluation. The parameters were analyzed using analysis of variance method (F test 5\%). The differences between treatments were evaluated by the Duncan Multiple Range Test (DMRT) at 5\% level of probability. The correlation test was used to find out the closeness between variables (Demir et al., 2011).

\section{RESULTS AND DISCUSSION}

\section{The effect of phosphorus (P) and potassium (K) nutrients on the vegetative growth of viola parent plants}

Results on the growth and seed production are summarized in Table 2. Based on the variance test $(\mathrm{F}$ test $=5 \%), \mathrm{P}$ and $\mathrm{K}$ nutrients significantly affect the number of leaves $(p<0.05)$ and give a highly significant effect $(p<0.01)$ on other variables.
Table 2. The result of combined ANOVA for growth and seed production of viola parent plants

\begin{tabular}{lcc}
\hline \multicolumn{1}{c}{ Variable } & Unit & F Test \\
\hline Plant height & Cm & $4.86^{* *}$ \\
Number of leaves & Sheet & $2.69^{*}$ \\
Number of flowers & Stalk & $4.02^{* *}$ \\
Number of seeds per & Grain & $8.43^{* *}$ \\
capsule & & \\
Seed production & G & $11.01^{* *}$ \\
Germination energy & $\%$ & $15.31^{* *}$ \\
\hline
\end{tabular}

Note: $* *=$ significant at level $p 0.01 ; *=$ significant at level $p 0.05$

\section{The height}

Plant height on P0 (Table 3) is the lowest $(10.46 \mathrm{~cm})$ because $\mathrm{P} 0$ is containing the lowest $\mathrm{P}$ and $\mathrm{K}$ nutrients during the growing period. Next, P6 and P3 have the highest relative plant height $(14.05 \mathrm{~cm}$ and $13.95 \mathrm{~cm})$. Those are close to the normal growth of viola plants, which is $15-20 \mathrm{~cm}$ at 14 weeks after transplanting (Giza and Wheler, 2015). The advantages of $P 6$ and $P 3$ in the vegetative stage are the highest level of $P$ and $K$ content, $1.08 \mathrm{~g}$ and $1.05 \mathrm{~g}$, respectively. The addition of $\mathrm{P}$ and $\mathrm{K}$ nutrients ( $\mathrm{P} 3$ treatment) was only given in the vegetative stage. The addition of $P$ nutrients was also given to the generative stage on P6 treatment. This study shows that the addition of $\mathrm{P}$ nutrients in the generative stage did not affect the plant height. 
Table 3. The effect of the addition of $\mathrm{P}$ and $\mathrm{K}$ fertilizers on the height and number of leaves of viola female parent plants

\begin{tabular}{lcc}
\hline \multicolumn{1}{c}{ Treatments } & Height $(\mathrm{cm})$ & Number of leaves (sheet) \\
\hline P0 (Standard) & $10.46 \mathrm{~b}$ & $76.25 \mathrm{c}$ \\
P1 (+P Veg) & $10.97 \mathrm{~b}$ & $116.25 \mathrm{abc}$ \\
P2 (+K Veg) & $11.22 \mathrm{~b}$ & $105.50 \mathrm{bc}$ \\
P3 (+PK Veg) & $13.95 \mathrm{a}$ & $174.00 \mathrm{a}$ \\
P4 (+P Veg +P Gen) & $11.37 \mathrm{~b}$ & $112.75 \mathrm{abc}$ \\
P5 (+K Veg +P Gen) & $11.97 \mathrm{~b}$ & $101.50 \mathrm{bc}$ \\
P6 (+PK Veg +P Gen) & $14.05 \mathrm{a}$ & $142.75 \mathrm{ab}$ \\
\hline
\end{tabular}

Note: Number followed by the same letter in same row is not significant at $p 0.05$ according to DMRT $\mathrm{P} 0=$ Vegetative $(\mathrm{HF}+\mathrm{CNO}+$ Magnisal), generative $(\mathrm{HF}+\mathrm{CNO}+\mathrm{HB}+\mathrm{HC}) ; \mathrm{P} 1=$ Vegetative (standard $+\mathrm{HB}) ; \mathrm{P} 2=$ Vegetative $($ standard $+\mathrm{HC}) ; \mathrm{P} 3=$ Vegetative $($ standard $+\mathrm{HB}+\mathrm{HC}) ; \mathrm{P} 4=$ Vegetative $($ standard $+\mathrm{HB})$, generative (standard $+\mathrm{HB}) ; \mathrm{P} 5=$ Vegetative $($ standard $+\mathrm{HC})$, generative (standard $+\mathrm{HB}) ; \mathrm{P} 6=$ Vegetative (standard $+\mathrm{HB}+\mathrm{HC}$ ), generative (standard $+\mathrm{HB})$

Plant height on $\mathrm{P} 1, \mathrm{P} 2, \mathrm{P} 4$ and $\mathrm{P} 5$ is statistically lower compared to the height on P3 and P6. This shows that the addition of both $\mathrm{P}$ and $\mathrm{K}$ nutrients in the vegetative stage put a better effect on the plant height. Plant height is useful for determining landscape design. Also, it is important to find the ideal height of viola as a landscape element. The ideal height of viola is 15 $\mathrm{cm}$ (Omidi et al., 2017) or half of the normal plant width of 25-30 cm (Gill and Owings, 2007). The plant height of P1 was similar to that of P4. This shows that the addition of $\mathrm{P}$ nutrient in the generative stage (P4) did not affect plant height. This result was similar to those in the P2 and P5 treatments where the addition of $\mathrm{P}$ nutrients to the generative stage did not significantly affect plant height. This is because N, P and $\mathrm{K}$ nutrient uptake for the vegetative organ growth occur more slowly in the generative stage. This causes viola plant height in P4 not significantly different with the height of P5 at the end of the observation period.

These results are in line with Viola odorata plant, that the supplies of $\mathrm{N}, \mathrm{P}$ and $\mathrm{K}$ nutrient in viola female parent plants must and have been fulfilled since the beginning of their growth (vegetative stage) (Fan and Morard, 1993). This is also supported by observations in the field that plants do not experience dwarf and have a lot of shoots, and their leaves, especially old leaves, are not pale yellow. Viola plants usually show symptoms of $\mathrm{P}$ and $\mathrm{K}$ nutrient deficiencies in vegetative stages such as inhibited root development and purple leaves so that nutrient absorption for growth such as height is disrupted.

$\mathrm{P}$ nutrient has a role in the formation of phospholipids in cell membranes but it also influences the process of divisional cell that increase plant height of viola. While $\mathrm{K}$ nutrient is needed in the process of photosynthesis and respiration that can also affect plant height. Similarly, Jamil et al. (2016); Zawadzisnka and Janicka (2007) reported that addition of $\mathrm{P}$ and $\mathrm{K}$ fertilizers on amaryllis and Viola wittrockiana plants could increase plant height up to $60 \mathrm{~cm}$ and $10.58 \mathrm{~cm}$, respectively.

\section{The number of leaves}

Statistically, the $\mathrm{P}$ and $\mathrm{K}$ nutrients significantly affect the number of leaves of the viola parent plants. The number of leaves of viola was the highest (174 sheets) in P3 treatment while it was not statistically significant (142.75 sheets) in P6 treatment. While $\mathrm{P} 0$ produced the lowest number of leaves, 76.25 sheets (Table 3). This is because $\mathrm{P} 3$ and $\mathrm{P} 6$ have the highest $\mathrm{P}$ and $\mathrm{K}$ content in the vegetative stage and $\mathrm{P}$ nutrient does not affect the generative stage. Furthermore, P0 has the lowest $\mathrm{P}$ and $\mathrm{K}$ nutrient content during the growing period of the viola parent plants.

The number of leaves P1 was equal to that of $\mathrm{P} 4$, where $\mathrm{P}$ nutrient was added in the vegetative stage. Furthermore, the number of leaves $\mathrm{P} 2$ was similar to that of P5, wherein at the vegetative stage, $\mathrm{K}$ was added. This confirms that the addition of $\mathrm{P}$ nutrient in the generative stage ( $\mathrm{P} 4$ and P5) did not increase the number of leaves. Nutrients that affect growth are the nutrients given at the vegetative growth stage. Fan and Morard (1993) reported the highest N, P and K nutrient uptake for the vegetative organs of Viola odorata plants occur in the vegetative stage.

Such a similar result was also obtained on chili plants. $\mathrm{P}$ increases the number of leaves. The $\mathrm{P}$ 
elements play an important role in the preparation of various important elements in plants such as nucleic acids. It is also being a storage and energy provider needed in the process of plant cell metabolism. The $\mathrm{P}$ element affects the formation of leaves and this causes the photosynthetic rate of plants to increase. Indirectly, it will cause energy to form a vegetative organ that is larger as indicated by the increase in the number of leaf organs, diameter and plant height (Pandiangan et al., 2015).

Furthermore, $\mathrm{K}$ nutrient (vegetative stage) given in the treatment was also influential. The $\mathrm{K}$ nutrient as in P3 and P6 treatments provided the highest number of leaves. This is in line with Safuan and Bahrun's (2012) which states that K can increase plant photosynthesis through increasing photophosphorylation, which produces ATP and NADPH that play a role in the process of photosynthesis and plant metabolism to increase the number of leaves. Then, the $\mathrm{K}$ concentration also has a positive correlation with the enlargement area in plants. Several physiological processes in a cell such as protein synthesis, carbohydrate metabolism and enzyme activation depend on it. When plants lack of $\mathrm{K}$, the division of cells is disrupted, and therefore, the process of forming new leaves will be disturbed. Similar in the research of melon plants with a dose of $200 \mathrm{~kg} \mathrm{~K}_{2} \mathrm{O}$ ha $^{-1}$ will increase the number of leaves.

The number of leaves was significantly and positively correlated to plant height variable (0.88). The higher parent plant will increase the number of leaves. High plants will contribute to more leaves because more segments and buds are formed. According to Bangun (2002), leaf formation patterns follow the leaf layout diagrams, which are called spiral (scattered) phylaxis. This type of location of leaves follows a spiral pattern with 5-8 rows or more of each stem segment. It is also found in plants with rosette shape. Thus, the higher plant caused by a large number of segments will have an impact by the increased number of leaves. In addition, a light absorption area will increase in higher plants. Photosynthate produced by the leaves in sufficient condition, so the results of metabolism will form proteins, enzymes, hormones and carbohydrates so that enlargement, extension and cell division take place rapidly in the leaf itself.

\section{The effect of $P$ and $K$ nutrients on the generative growth of viola parent plants}

Based on the variance test $(\mathrm{F}$ test $=5 \%), \mathrm{P}$ and $\mathrm{K}$ nutrients significantly affect the number of flowers, the number of seeds per capsule and the yield of the parent plant at 10 weeks of pollination (Table 4).

Table 4. The effect of the addition of $\mathrm{P}$ and $\mathrm{K}$ fertilizers on yield variable of viola female parent plants

\begin{tabular}{|c|c|c|c|}
\hline Treatments & $\begin{array}{c}\text { Number of flowers } \\
\text { (stalk) }\end{array}$ & $\begin{array}{l}\text { Number of seed per } \\
\text { capsule (grain) }\end{array}$ & $\begin{array}{l}\text { Seed production } \\
\left(\mathrm{g} \mathrm{plant}^{-1}\right)\end{array}$ \\
\hline P0 (Standard) & $93.17 \mathrm{c}$ & $25.25 \mathrm{~d}$ & $1.91 \mathrm{e}$ \\
\hline $\mathrm{P} 1(+\mathrm{P}$ Veg) & $107.67 \mathrm{bc}$ & $32.58 \mathrm{bc}$ & $2.05 \mathrm{de}$ \\
\hline P2 (+K Veg) & $109.67 \mathrm{bc}$ & $30.44 \mathrm{~cd}$ & $2.23 \mathrm{de}$ \\
\hline P3 (+PK Veg) & $133.92 \mathrm{ab}$ & $33.92 \mathrm{bc}$ & $2.85 \mathrm{ab}$ \\
\hline $\mathrm{P} 4$ (+P Veg +P Gen) & $116.33 \mathrm{ab}$ & $35.25 \mathrm{bc}$ & $2.33 \mathrm{~cd}$ \\
\hline P5 (+K Veg +P Gen) & $111.75 \mathrm{bc}$ & 39.11 bo & $2.78 \mathrm{bc}$ \\
\hline P6 (+PK Veg +P Gen) & $137.92 \mathrm{a}$ & $46.53 \mathrm{a}$ & $3.24 \mathrm{a}$ \\
\hline
\end{tabular}

Note: Number followed by the same letter in same row is not significant at $p 0.05$ according to DMRT

$\mathrm{P} 0=$ Vegetative $(\mathrm{HF}+\mathrm{CNO}+$ Magnisal $)$, generative $(\mathrm{HF}+\mathrm{CNO}+\mathrm{HB}+\mathrm{HC}) ; \mathrm{P} 1=$ Vegetative (standard $+\mathrm{HB}) ; \mathrm{P} 2$ = Vegetative $($ standard $+\mathrm{HC}) ; \mathrm{P} 3=$ Vegetative $($ standard $+\mathrm{HB}+\mathrm{HC}) ; \mathrm{P} 4=$ Vegetative (standard $+\mathrm{HB})$, generative $($ standard $+\mathrm{HB}) ; \mathrm{P} 5=$ Vegetative $($ standard $+\mathrm{HC})$, generative $($ standard $+\mathrm{HB}) ; \mathrm{P} 6=$ Vegetative (standard $+\mathrm{HB}+\mathrm{HC}$ ), generative (standard $+\mathrm{HB})$

\section{Number of flower}

Table 4 shows that the number of flower was relative the highest (137.92 stalks) in P6 but equal to (133.92 stalks) that of $\mathrm{P} 3$. The addition of $\mathrm{P}$ and $\mathrm{K}$ nutrients (P3) was only given in the vegetative stage. Whereas, in P6, the addition of P nutrient was also given in the generative stage. This shows that the addition of $\mathrm{P}$ nutrient in the generative stage does not increase the number of flowers. Then, P0 shows the lowest number of flowers 
(93.17 stalks). This is because P0 contains the lowest $\mathrm{P}$ and $\mathrm{K}$ nutrients during the growing period. The $\mathrm{P}$ is used by plants to transport metabolic energy in plants and stimulate flowering. While $\mathrm{K}$ works in photosynthesis, transport of assimilate, enzymes and minerals, including water for flower formation (Wardhani et al., 2014).

The number of flower P1 was similar to that of $\mathrm{P} 4$, due to the vegetative stage that was only given $P$. This also indicates that the addition of $P$ nutrients in the generative stage (P4) did not affect the number of flowers. The P2 was equal to that of P5 because in the vegetative stage, it was only given $\mathrm{K}$. This also indicates that the addition of $\mathrm{P}$ nutrient in the generative stage (P5) did not affect the number of flowers. This result was also supported by research on Viola odorata plants. The $\mathrm{P}$ and $\mathrm{K}$ nutrients uptake starts from vegetative growth, but there is a high concentration of $\mathrm{P}$ nutrient in the generative organs such as flowers. It is revealed that $\mathrm{K}$ is mostly absorbed by these plants at the end of flowering (Fan and Morard, 1993) so the results are statistically the same if the $\mathrm{P}$ and $\mathrm{K}$ nutrients are given only in the generative stage or in the vegetative stage separately.

The $\mathrm{P}$ nutrient is required by plants to form flowers because these nutrients play a role in the photosynthesis process, the results are used to form flower organs. If the availability is reduced, the energy to produce flowers will be interrupted. Besides, phosphate nutrient plays an active role in the energy transferring process and the process of reforming carbohydrates into sugars and increases the work efficiency of chloroplasts. Hence, when there are more phosphate contents absorbed, the flowers induction and fruit will be formed faster (Priyambudi et al., 2017).

The P nutrient, as in the research of the Viola tricolor, can significantly increase the ability of plants to flower and germinate pollen produced by the plant's flowers. Then simultaneously increasing $\mathrm{K}$ nutrient will function as an accelerator for transferring carbohydrates to the location of the generative organs as an energy source for the formation of generative organ such as flowers. Furthermore, the number of flowers was positively correlated to the height and the number of leaves (0.97 and 0.95 , respectively). The higher plant and the greater number of leaves will produce a higher number of flowers of viola female parent plants. In addition, a large number of leaves will contribute to the production of photosynthates from the leaves which are increasingly large as the flower-forming material.

The correlation between the number of flowers and the number of leaves is also presented in the research on Murraya paniculata plants. The correlation indicated that an increase in the number of leaves and the number of branches multiplies the number of flowers. This is because the formation of leaves beginning at the end allows the formation of a flower starter which determines the number of leaves. Furthermore, the secondary branches and the highest levels generally have one or two leaves less than the primary shoots because they appear later and receive environmental cues for flowering (Gardner, 1991; Syahadat and Aziz, 2013).

\section{The number of seeds per capsule}

$\mathrm{P}$ and $\mathrm{K}$ nutrients were statistically significant on the number of seeds per capsule at the end of the observation period. The number of seeds per capsule was the highest (46.35 grains) in P6 (Table 4). The P6 was significantly different from $\mathrm{P} 3$. This indicates the effect of the $\mathrm{P}$ addition on the generative stage. This is similar to the previous studies on Nigella sativa. Seed per capsule of Nigella sativa increases up to 60 grain in $20 \mathrm{~kg} \mathrm{ha}^{-1} \mathrm{P}$ (Tuncturk et al., 2011). This is due to the fact, higher dry weight of canopy related to $\mathrm{P}$ and $\mathrm{K}$ nutrients can increase the crop biomass production. The dry weight of the canopy is accumulated of photosynthates. Photosynthates will be translocated to the seeds. Flowers and fruit have the highest possibility of sinking. If the assimilation in the leaves is low, the weight of the seeds and the number of seeds are also reduced (Kuntyastuti and Lestari, 2017)

Statistically, the P6 had a higher number of seeds per capsule from $\mathrm{P} 4$ and $\mathrm{P} 5$. The addition of $\mathrm{P}(\mathrm{P} 4)$ or K nutrient (P5) in the vegetative stage statistically produced less number of seeds per plant compared to the addition of $\mathrm{P}$ and $\mathrm{K}$ (P6). The production of viola seeds was significantly different, by increasing $\mathrm{P}$ and $\mathrm{K}$ nutrients. Furthermore, P0 shows the lowest number of seeds per capsule (25.25 grains). The P0 could only produce a half of the number of seeds of P6 treatment. This is because $\mathrm{P}$ and $\mathrm{K}$ nutrient content of $\mathrm{P} 0$ during growth period until the end of generative stage was the lowest, $1.36 \mathrm{~g}$ and $1.29 \mathrm{~g}$, respectively. 
Increasing the number of seeds begins with the previous pollination process. The entry of pollen into the stigma starts the process of fertilization in the viola plant. Similar to the research on Viola tricolor plant, increasing $\mathrm{P}$ nutrients significantly increase the pollen germination up to $47 \%$ (Miyajuma, 2006). The addition of $\mathrm{P}$ increases the number of viola seeds.

The number of seed per capsule was positively correlated to the number of leaves and the number of flowers (0.85 and 0.77, respectively). Increasing the number of leaves and the number of flowers escalated the number of seeds per fruit. These findings is also confirmed by the research by Novrika and Herison (2016) and Murniati et al. (2013). The results of their studies show that the number of leaves causes much light absorbed for photosynthesis so carbohydrates for plant growth are also increasing. Assimilates are distributed to the receiving organs (sinks). The good transport system is needed because the rate of assimilate translocation runs optimally. This result is also influenced by the availability of $\mathrm{P}$ and $\mathrm{K}$ nutrients that accelerate the formation of seeds. Dwiputra et al. (2015) reported the increasing photosynthate can increase the number of seeds produced by the parent plants. In addition to assimilates, the maturity of pollen can also be accelerated when there is sufficient sunlight so that the fertilization process occurs more completely.

\section{The seed production}

$\mathrm{P}$ and $\mathrm{K}$ nutrients significantly affected the seed production at the end of the observation period. Seed production was the highest $(3.24 \mathrm{~g}$ plant $^{-1}$ ) in P6 treatment while there was no statically difference $\left(2.85 \mathrm{~g} \mathrm{plant}^{-1}\right)$ in P3 treatment. This is similar to some of the previous variables. Furthermore, this productivity can fulfill the standard seed production in tropical countries, which are more than $2 \mathrm{~g}$ plant $^{-1}$ (personal communication).

In the generative stage, the $\mathrm{P}$ and $\mathrm{K}$ nutrients, $\mathrm{P} 2.77 \mathrm{~g}$ and $\mathrm{K} 2.56 \mathrm{~g}$, were given since the beginning of growth in P6 treatment. This treatment had the highest $\mathrm{P}$ and $\mathrm{K}$ nutrients compared to the other treatments at the end of the generative stage. This exposes that seed production was not affected by the addition of $\mathrm{P}$ nutrients in the generative stage. Therefore, the productivity of viola parent plants, particularly between $\mathrm{P} 3$ and P6, at the end of the generative period was statistically the same. This is similar to the studies on the marigold parent plants. $\mathrm{P}$ and $\mathrm{K}$ nutrients can affect plant growth and are positively correlated to seed production. The dose of fertilizing $10 \mathrm{~g} \mathrm{~m}^{-1} \mathrm{P}$ and $15 \mathrm{~g} \mathrm{~m}^{-1} \mathrm{~K}$ increased the seed production of marigold from $10.31 \mathrm{~g}$ plant $^{-1}$ to 18.78 g plant $^{-1}$ (Aslam et al., 2016).

Furthermore, seed production was the lowest (1.91 $\mathrm{g} \mathrm{plant}^{-1}$ ) in P0 treatment. This shows that P0 cannot produce seeds exceeding the standards productivity of the viola female parent plants in tropical countries. This is because the nutrient contents of P0 treatment were lowest, P $1.36 \mathrm{~g}$ and $\mathrm{K} 1.29 \mathrm{~g}$.

Seed production on $\mathrm{P} 1, \mathrm{P} 2, \mathrm{P} 4$ and $\mathrm{P} 5$ treatments were statistically lower, compared to those of P3 and P6. This pinpoints that the addition of $\mathrm{P}$ and $\mathrm{K}$ nutrients in the vegetative stage gave a better effect on the seed production. The P1 was similar to that of P2 (2.05 g plant ${ }^{-1}$ and $2.23 \mathrm{~g} \mathrm{plant}^{-1}$, respectively). This reveals that the addition of $\mathrm{P}(\mathrm{P} 1)$ or $\mathrm{K}$ only $(\mathrm{P} 2)$ in the vegetative stage did not affect seed production. The $\mathrm{P} 4$ was equal to P5. Even though the additional $\mathrm{P}$ was given in the generative stage, the addition of $\mathrm{P}$ (P4) or K (P5) during the vegetative stage did not affect the seed production.

This is similar to the results of Komalasari and Fauziah (2011) and Umar's (2012) research. P and $\mathrm{K}$ nutrients are needed in the generative stage for filling the seed. In addition, the vegetative performance also affects the seed production. Furthermore, the research on corn and soybeans shows that a balanced application of $\mathrm{P}$ and $\mathrm{K}$ can increase seed production and specific gravity of the seeds. Therefore, to obtain a good plant yield, the nutrient elements of $\mathrm{P}$ and $\mathrm{K}$ in the soil must be sufficiently available at the seed filling stage.

Technically, $P$ is the key to various biosynthetic processes in plant cells and organs. It is involved in all plant metabolic processes and contributes to the formation of the structural compounds for reproductive purposes and energy transfer conversion. Consequently, $\mathrm{P}$ fertilizer can increase the ability in the filling of seeds filling (photosynthate transport) harvested at various levels of development. The $\mathrm{P}$ nutrient accelerates the process of seed maturation to improve the seed quality. Thus, productivity can increase as in various soybean varieties (Krueger, 2011; Yusmar et al., 2014).

The seed production was positively correlated to the number of flowers and the number of seeds per fruits (0.92 and 0.88 , respectively). The higher 
number of flowers and the higher number of seeds per plant directly produce the higher seed production. This is because the weight of seeds is affected by the number of perfect seeds formed, with the process beginning with flowering. The formation of flowers and seeds are also affected by the vegetative growth performance of the viola parent plant.

\section{The seed germination energy}

The P0 treatment produced the lowest germination energy (64.5\%). This shows that the P0 cannot provide germination according to the standard of market requirements. This is because the nutrient content during the vegetative and generative periods is the lowest and contributes to the lowest plant performance.

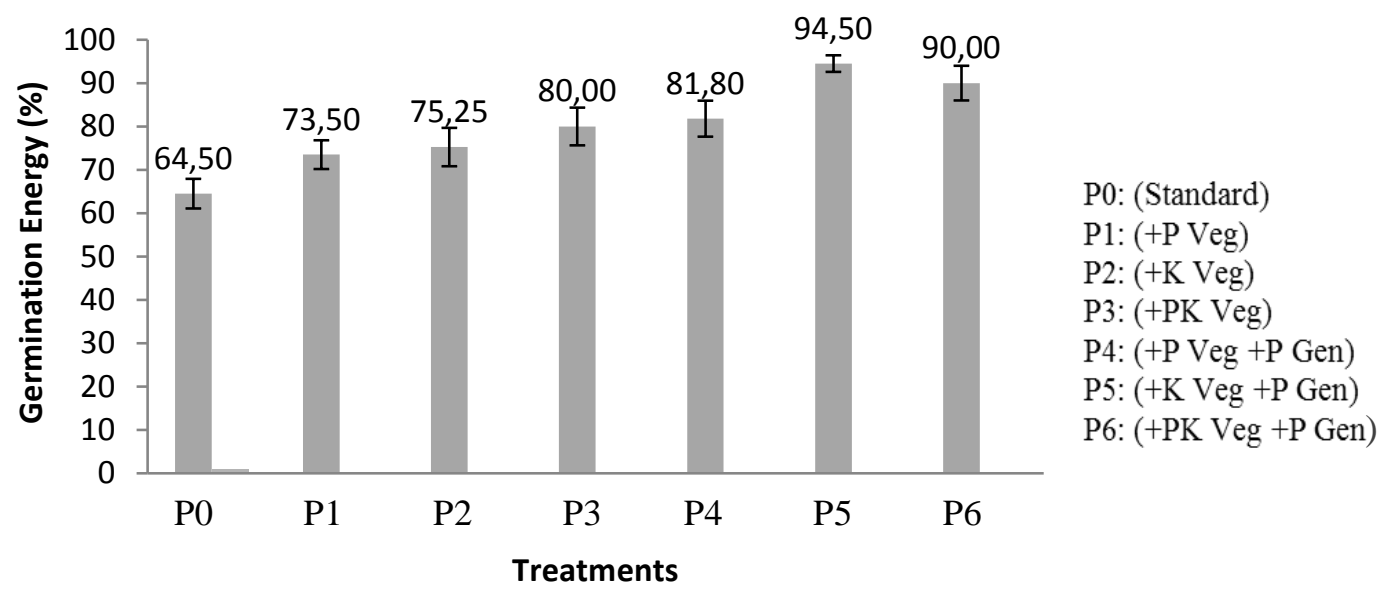

Figure 1. The combination of $\mathrm{P}$ and $\mathrm{K}$ on the germination of viola extension seeds according to DMRT at $p 0.05$

Note: $\mathrm{P} 0=$ Vegetative $(\mathrm{HF}+\mathrm{CNO}+$ Magnisal $)$, generative $(\mathrm{HF}+\mathrm{CNO}+\mathrm{HB}+\mathrm{HC}) ; \mathrm{P} 1=$ Vegetative (standard $+\mathrm{HB}) ; \mathrm{P} 2=$ Vegetative $($ standard $+\mathrm{HC}) ; \mathrm{P} 3=$ Vegetative $($ standard $+\mathrm{HB}+\mathrm{HC}) ; \mathrm{P} 4=$ Vegetative $($ standard $+\mathrm{HB})$, generative (standard $+\mathrm{HB}) ; \mathrm{P} 5=$ Vegetative $($ standard $+\mathrm{HC})$, generative $($ standard $+\mathrm{HB}) ; \mathrm{P} 6=$ Vegetative (standard $+\mathrm{HB}+\mathrm{HC}$ ), generative (standard $+\mathrm{HB}$ )

Furthermore, $\mathrm{P}$ nutrients in the generative stage significantly influence the germination energy of viola seeds. The highest germination energy $(94.5 \%)$ was in P5, while it was statistically the same as in P6 (90\%) (Figure 1). This result is different from the other results and has fulfilled the germination energy standard of viola extension seeds in the market.

The application of $\mathrm{P}$ during the generative stage increases the generative growth of viola plants and directly increases the yields and the quality of extension seeds. This is in line with the previous research which confirms high $\mathrm{P}$ levels in seeds and fruit. $\mathrm{P}$ nutrients are considered important for the formation of seeds and fruit and influence the germination of seeds. The results of a study by Yusuf et al. (2014) show that P nutrient causes the seeds to have food reserves and have a larger embryo. The $\mathrm{P}$ element is an essential nutrient of living cells, such as parts of the nucleotides and phospholipids of a membrane. In the seed, it is stored as phytin, which consists of calcium and magnesium salts of phytic acid. The process of seed maturity requires adequate nutrients and most of the $\mathrm{P}$ in the seeds is phytin. Phytin will be used as the main source of energy for seeds during the germination process. This compound functions as a source of energy used during germination. Some studies concluded that phytin affected seed vigor (Salisbury and Ross, 1992). The study carried out by Lesilolo (2012) strengthens that increasing the dose of it to $70 \mathrm{~kg}$ $\mathrm{ha}^{-1}$ in corn plants statically increases the germination, growth speed, normal sprouts and the length of the primary roots of the sprouts.

Furthermore, this is similar to the results of several studies. SP-36 fertilizer can accelerate flowering as a first step in the seed production process. In soybean plants, the supply of $\mathrm{P}$ fertilizer as much as $150 \mathrm{~kg} \mathrm{ha}^{-1}$ can improve the physiological quality of seeds. The germination of soybean seeds is up to $90 \%$ (Pandiangan et al., 2015). This is similar to the other research that soybean plants fertilized with SP-36 $300 \mathrm{~kg} \mathrm{ha}^{-1}$ 
have the germination capacity of $96 \%$. Moreover, the SP-36 fertilized plants $250 \mathrm{~kg} \mathrm{ha}^{-1}$ seeds viability is up to $72 \%$ (Umar, 2012; Yusmar et al., 2014).

The germination energy of P6 was relatively lower than that of P5. The number of seeds per capsule of P6 was higher than that P5 (Table 4). Thus, nutrients are divided into a higher number of seeds. The seed filling process was not as optimal as that in P5 and decreased in viability. $\mathrm{K}$ nutrients in the vegetative stage on P5 could increase plant growth through optimal root formation that could be used for seed formation. $\mathrm{K}$ also served as photosynthate translocator and formed carbohydrates as an endosperm (Fitriesa et al., 2017).

The seed germination of P1, P2, P3 treatments did not show any differences. This fortifies that the germination energy was not affected by the addition of $\mathrm{P}, \mathrm{K}$ or $\mathrm{PK}$ nutrients in the vegetative stage. Whereas, in $\mathrm{P} 4$ treatment, $\mathrm{P}$ nutrient was added in the generative stage, but $\mathrm{K}$ nutrient was not added in the vegetative stage, and therefore, the plant performance was lower than that in P3. Consequently, P1, P2 and P3 show similar results. This also exposes that plant performance at the beginning of growth affects the variable of seed quality.

The germination energy was positively correlated to the number of leaves (0.77). Such similar results were also obtained by Asih et al. (2017). Cereal crops such as corn and wheat, which have similarities in flowers, are multiovulate flower, like viola. Positive interactions were shown between the number of leaves and the seed viability. In corn plant with 6sheet leaves produce the germination of $85 \%$. Whereas, in plants with 5 -sheet leaves produce germination of $51 \%$. This is because the high number of leaves will have an impact on the broader canopy as a net photosynthate producer to support the filling and maturity of seeds.

\section{CONCLUSIONS}

Higher $\mathrm{P}$ and $\mathrm{K}$ nutrients in fertilizer mixture significantly increase the number of leaves and are highly significant on the height, number of flowers, number of seeds per fruit, seed production and germination energy of viola seeds. The addition of both $\mathrm{P}$ and $\mathrm{K}$ fertilizers in the vegetative stage and $\mathrm{P}$ in the generative stage (P6) results in germination energy of $\geq 90 \%$ and highest seed production, which is $3.24 \mathrm{~g}$ of plant ${ }^{-1}$.

\section{REFERENCES}

Asih, P. R., \& Surahman, M. (2017). Isolasi Rhizobakteri dan Pengaruh Aplikasinya dengan Pupuk N-P terhadap Mutu Benih dan Pertumbuhan Bibit Tetua Betina Jagung. Agron, 45(3), 255-262. Retrieved from http://journal.ipb.ac.id/index.php/jurnalagrono $\mathrm{mi} /$ article/view/13138

Aslam, A., Zaman, F., Qasim, M., Ziaf, K., Shaheen, I., Afzal, N., \& Hussain, S. (2016). Impact of Nitrogen and Potash on Growth , Flower and Seed Yield of African Marigold (Tagetes erecta L .). Scientia Agriculture, 14(2), 14-17. https://doi.org/10.15192/PSCP. SA.2016

Bangun, A. P. (2002). Phyllotaxis. Jakarta: Erlangga.

Demir, I., Celikkol, T., Sarıkamıs, G., \& Eksi, C. (2011). Vigor Tests to Estimate Seedling Emergence Potential and Longevity in Viola Seed Lots. Hort Science, 46(3), 402-405. Retrieved from https://journals.ashs.org/ hortsci/view/journals/hortsci/46/3/articlep402.xml

Dwiputra, A. H., Indradewa, D., \& Susila, E. T. (2015). Hubungan Komponen Hasil Dan Hasil Tiga Belas Kultivar Kedelai (Glycine max (L.) Merr.). Vegetalika, 4(3), 14-28. Retrieved from https://jurnal.ugm.ac.id/jbp/article/view/ 10474

Fan, A. S. S., \& Morard, P. (1993). Nutrient uptake by Toulouse violet (Viola odorata var. parmensis) during its developmental cycle. Optimization of Plant Nutrition, 269-275. https://doi.org/10.1007/978-94-017-2496-8_ 42

Fitriesa, S., Sari, M., \& Suhartanto, M. R. (2017). Pengaruh Pemupukan N, P, dan K pada Dua Varietas Benih Kedelai (Glycine Max (L) Merr.) terhadap Kandungan Antosianin dan Hubungannya dengan Vigor Benih. Buletin Agrohorti, 5(1), 117-125. https://doi.org/10. 29244/agrob.5.1.117-125

Gardner. (1991). Fisiologi Tanaman Budidaya. Jakarta: UI Press. 
Gill, D., \& Owings, D. A. (2007). Bedding Plants for Louisiana Landscapes. Retrieved from https://www.lsuagcenter.com/NR/rdonlyres/5 00D171D-0BB6-4D99-9A9E-5FD4B3C85F6 D/38048/pub2747beddingplantsHIGHRES1.p df

Giza, J., \& Wheler B. (2015). Family Name: Violaceae. Enviromental studies. Retrieved from https://www.lakeforest.edu/academics/ programs/environmental/courses/es203/viola_ pedata.ph

Jamil, M. K. J., Ahman, M. M. I. R., \& Ossain, M. M. O. H. (2016). Response of N, P and K On The Growth and Flowering of Hippeastrum (Hippeastrum hybridum Hort.). Jurnal Agril, 41(1), 91-101. Retrieved from https://www.researchgate.net/publication/302 631132_Response_of_N_P_and_K_on_the_ growth_and_flowering_of_hippeastrum_Hipp eastrum_hybridum_Hort

Janicka, D., \& Dobrowolska, A. (2013). Effect Of Organic Media On Growth And Development Of Viola cornuta. Acta Agrobotanica, 66(1), 95-104. https://doi.org/10.5586/aa.2013.011

Komalasari, O., \& Fauziah. (2011). Pengaruh Kualitas Biji Pada Berbagai Taraf Pemupukan Nitrogen Terhadap Vigor Benih Jagung. Cerealia Nasional Proceeding, 27, 1-11. Retrieved from https://www.google.com/url $? \mathrm{sa}=\mathrm{t} \& \mathrm{rct}=\mathrm{j} \& \mathrm{q}=\& \mathrm{esrc}=\mathrm{s} \&$ source $=$ web $\& \mathrm{~cd}=1$ $\&$ cad $=$ rja \&uact $=8 \&$ ved $=2$ ahUKEwi $24 \mathrm{t} 3 \mathrm{yys} D$ kAhULPo8KHV77CvIQFjAAegQIABAC\&u $\mathrm{rl}=\mathrm{http} \% 3 \mathrm{~A} \% 2 \mathrm{~F} \% 2 \mathrm{Fbalitsereal.litbang.pertan}$ ian.go.id\%2Fwp-content $\% 2$ Fuploads $\% 2 \mathrm{~F} 20$ $16 \% 2 \mathrm{~F} 12 \% 2 \mathrm{~F} 44$. pdf\&usg=AOvVaw1u-CC p4lHMraqdy1qu9FKp

Krueger, K. (2011). Effects of phosphorus and potassium fertilization rate and placement method on soybean (Glycine max L .) seed quality and long-term storability. Dissertation, $M \quad S c(12217), 99 . \quad$ Retrieved from https://www.researchgate.net/publication/241 809285_Effects_of_phosphorus_and_potassiu m_fertilization_rate_and_placement_method_ on_soybean_Glycine_max_L_seed_quality_a nd_long-term_storability

Kuntyastuti, H., \& Lestari, S. A. D. (2017). Pengaruh Interaksi antara Dosis Pupuk dan Populasi Tanaman terhadap Pertumbuhan dan Hasil Kacang Hijau pada Lahan Kering
Beriklim Kering. Jurnal Penelitian Pertanian Tanaman Pangan, 35(3), 239-250. Retrieved from

https://www.neliti.com/publications/139201/p engaruh-interaksi-antara-dosis-pupuk-danpopulasi-tanaman-terhadap-pertumbuhan

Lazcano, C., \& Dominguez, J. (2010). Effects of vermicompost as a potting amendment of two commercially-grown ornamental plant species (Viola wittrockiana and Primulas). Spanish Journal of Agricultural Research, 8(4), 12601270. Retrieved from http://revistas.inia. es/index.php/sjar/article/view/1412/0

Lesilolo, M. K. (2012). Studi Pemupukan Fosfat Terhadap Viabilitas Dan Vigor Benih Jagung (Zea mays L.) Varietas Hulaliu. Agrologia, 1(2), 119-125. https://doi.org/10.30598/a.vli 2.287

Ma'rufah, D. (2008). Pengisian Biji. Surakarta: Universitas Sebelas MAret.

Maulana, Yetti, H., \& Yoseva, S. (2015). Pengaruh Pemberian Pupuk Bokashi dan NPK Terhadap Pertumbuhan dan Produksi Tanaman Jagung Manis (Zea mays Var saccharata Sturt). Jom Faperta, 2(2), 1-12. https://doi.org/10.16362/j.cnki.cn61-1457/h. 2017.02.010

Miyajuma, D. (2006). Pollination and seed Production in Viola. Hort Science, 41(3), 633639. Retrieved from https://journals.ashs. org/hortsci/view/journals/hortsci/41/3/articlep633.xml

Murniati, N. S., Setyono, \& Adimihardja, S. A. (2013). Analisis Korelasi dan Sidik Lintas Peubah Pertumbuhan Terhadap Produksi Cabai Merah (Capsicum Annuum L.). Jurnal Pertanian, 3(2), 111-121. Retrieved from https://ojs.unida.ac.id/jp/article/view/602

Novrika, D., \& Herison, C. (2016). Korelasi Antar Komponen Pertumbuhan Vegetatif dan Generatif dengan Hasil pada Delapan Belas Genotipe Gandum di Dataran Tinggi Correlation Between Vegetative and Generative Growth Components. Akta Agrosia, 19(2), 93-103. Retrieved from https://ejournal.unib.ac.id/index.php/Agrosia/ article/view/3704

Omidi, J., Abdolmohammadi, S., Hatamzadeh, A., \& Mahboub, A. (2017). Effect of the 
application of composted peanut shells on soil growing media on growth and nutrient elements of viola spp. International Journal of Farming and Allied Sciences, 6(5), 120-125. Retrieved from http://ijfas.com/wp-content/ uploads/2017/10/120-1253.pdf

Oh, W., Runkle, E. S., \& Warner, R. M. (2010). Timing and Duration of Supplemental Lighting during the Seedling Stage Influence Quality and Flowering in Petunia and Pansy (Viola Wittrockiana). Hort Science, 45(9), 1332-1337. Retrieved from https://journals. ashs.org/hortsci/view/journals/hortsci/45/9/art icle-p1332.xml

Pandiangan, E., Mariati, \& Ginting, J. (2015). Respons Pembungaan dan Hasil Biji Bawang Merah Terhadap Aplikasi GA3 dan Fosfor Response. Jurnal Online Agroekoteknologi, 3(c), 2-3. Retrieved from https://jurnal.usu. ac.id/index.php/agroekoteknologi/article/view /10976

Priyambudi, E., Sitawati, \& Nugroho, A. (2017). Pengaruh Model Penanaman dan Aplikasi Pupuk P dan K Pada Pertumbuhan dan Hasil Tanaman Stroberi. Jurnal Produksi Tanaman, 5(6), 917-924. Retrieved from http://protan. studentjournal.ub.ac.id/index.php/protan/articl e/view/460

Rawat, J., Sanwal, P., \& Saxena, J. (2016). Potassium and Its Role in Sustainable Agriculture. (December 2017). https://doi.org/ 10.1007/978-81-322-2776-2

Safuan, L. O., \& Bahrun. (2012). Pengaruh Bahan Organik Dan Pupuk Kalium Terhadap Pertumbuhan Dan Produksi Tanaman Melon (Cucumis melo L .). Jurnal Agroteknos, 2(2), 69-76. Retrieved from http://faperta.uho. ac.id/agroteknos/Daftar_Jurnal/2012/2012-202-SAFUAN.pdf

Salisbury, F. B., \& Ross, C. W. (1992). Plant Physiology. Wardworth Publishing Company, Inc. Belmont. CA.

Syahadat, R. M., \& Aziz, S. A. (2013). Hubungan Jumlah Bunga, Jumlah Daun, Jumlah Anak Daun, Jumlah Cabang, dan Tinggi Tanaman Terhadap Pertumbuhan Bibit Tanaman Kemuning (Murraya paniculata (L.) Jack). Jurnal Lanskap Indonesia, 5(1), 23-25.
Retrieved from http://journal.ipb.ac.id/index. php/jli/article/view/11140

Tuncturk, M., Tuncturk, R., \& Yildirim, B. (2011). Tuncturk, M., Tuncturk, R., \& Yildirim, B. (2011). The effects of varying phosphorus doses on yield and some yield components of black cumin (Nigella sativa L.). Advances in Environmental Biology, 5(2), 371-374. Retrieved from https://www.re searchgate.net/publication/289369409

Umar, S. (2012). Pengaruh Pemberian Bahan Organik Terhadap Daya Simpan Benih Kedelai (Glycine $\max$ (L.) Merr.). Berita Biologi, 11(3), 401-410. https://doi.org/10. 2105/ajph.81.7.839

Wardhani, S., Purwanti, K., \& Anugerahani, W. (2014). Pengaruh Aplikasi Pupuk Hayati Terhadap Pertumbuhan dan Produktivitas Tanaman Cabai Rawit (Capsicum frutescens L.) Varietas Bhaskara di PT Petrokimia Gresik. Jurnal Sains Dan Seni Pomits, 2(1), 2337-3520. Retrieved from http://digilib. its.ac.id/public/ITS-paper-33779-

1509100008-pomits-paper.pdf

Yusmar, M., Rasyad, A., \& Elfina, Y. (2014). Perkembangan Biji dan Mutu Benih Beberapa Genotipe Kedelai yang Diberi Pupuk P. Agrotek. Trop, 3(1), 6-11. Retrieved from https://www.neliti.com/id/publications/25896 6/perkembangan-biji-dan-mutu-benih-bebera pa-genotipe-kedelai-yang-diberi-pupuk-p

Yusuf, C. S., Makate, N., \& Jacob, R. (2014). Effect of seed size on germination and early growth of. Int. Journal of Scientific and Research Publications, 4(10), 4-6. Retrieved from http://www.ijsrp.org/research-paper-101 4/ijsrp-p3424.pdf

Zabua tech and data service. (2018). Impor Export Data Service. Retrieved from https://www. zauba.com/USA-imports-exports/Imports

Zawadzisnka, A., \& Janicka, D. (2007). Effects Of Compost Media On Growth and Flowering Of Parviflorous Garden Pansy (Viola Wittrockiana Gams. Acta Agrobotanica, 60(2), 161-166. Retrieved from http://agro.icm. edu.pl/agro/element/bwmeta1.element.agroarticle-dde1 f92c-dcb8-4ab9-b6a3-fc1 fbdb39 712/c/1781-4306-1-PB_167.pdf. 